\title{
Three dimensional ultrastructure of human respiratory cilia in health and disease
}

\author{
A Shoemark ${ }^{1,2^{*}}$, T Burgoyne ${ }^{2}$, M Dixon ${ }^{1}$, P Luther ${ }^{2}$, C Hogg $^{1}$ \\ From First International Cilia in Development and Disease Scientific Conference (2012) \\ London, UK. 16-18 May 2012
}

Motile cilia in the respiratory tract beat to clear mucus from the airways, keeping the lung clean and free from infection. In the inherited genetic condition Primary Ciliary Dyskinesia (PCD) cilia beat is ineffective, resulting in chronic cough, recurrent chest infections and rhinosinustitis. The definitive diagnostic test for PCD is electron microscopy of ciliary ultrastructure. There are a number of known ultrastructural defects associated with PCD. We have recently established the first three dimensional model of human respiratory cilia ultrastructure using electron tomography. Electron tomography is an electron microscopy technique which allows increased resolution and visualisation of structures in three dimensions. Our model highlights key features of the axoneme which cannot be resolved using traditional electron microscopy. The aim of this study was to characterise in 3D the ultrastructure of defects associated with PCD using the normal model as a template. Tomograms of transverse and longitudinal sections of cilia were generated from nasal brush biopsies taken from patients with PCD. Key features of the cilium were resolved using sub- volume or sub-tomographic averaging and measured. We show in detail the ultrastructural phenotype of radial spoke, dynein arm and central pair defects allowing insight into the structure of human respiratory tract cilium and primary ciliary dyskinesia.

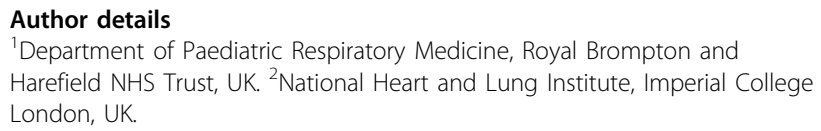

Published: 16 November 2012

\footnotetext{
* Correspondence: a.shoemark@rbht.nhs.uk

${ }^{1}$ Department of Paediatric Respiratory Medicine, Royal Brompton and Harefield NHS Trust, UK

Full list of author information is available at the end of the article
}

doi:10.1186/2046-2530-1-S1-P47

Cite this article as: Shoemark et al:: Three dimensional ultrastructure of human respiratory cilia in health and disease. Cilia 2012 1(Suppl 1):P47.
Submit your next manuscript to BioMed Central and take full advantage of:

- Convenient online submission

- Thorough peer review

- No space constraints or color figure charges

- Immediate publication on acceptance

- Inclusion in PubMed, CAS, Scopus and Google Scholar

- Research which is freely available for redistribution

Submit your manuscript at www.biomedcentral.com/submit

\section{() Biomed Central}

C Biomed Central

(c) 2012 Shoemark et al; licensee BioMed Central Ltd. This is an Open Access article distributed under the terms of the Creative Commons Attribution License (http://creativecommons.org/licenses/by/2.0), which permits unrestricted use, distribution, and reproduction in any medium, provided the original work is properly cited. 